University of Nebraska - Lincoln

DigitalCommons@University of Nebraska - Lincoln

USDA Forest Service / UNL Faculty Publications U.S. Department of Agriculture: Forest Service --

National Agroforestry Center

2010

\title{
Blister rusts in China: hosts, pathogens, and management
}

X. Y. Zhang

Chinese Academy of Forestry

Q. Lu

Chinese Academy of Forestry, luquan@caf.ac.cn

R. A. Sniezko

USDA Forest Service

R. Q. Song

Northeast Forestry University

G. Man

USDA Forest Service

Follow this and additional works at: https://digitalcommons.unl.edu/usdafsfacpub

Part of the Forest Sciences Commons

Zhang, X. Y.; Lu, Q.; Sniezko, R. A.; Song, R. Q.; and Man, G., "Blister rusts in China: hosts, pathogens, and management" (2010). USDA Forest Service / UNL Faculty Publications. 146.

https://digitalcommons.unl.edu/usdafsfacpub/146

This Article is brought to you for free and open access by the U.S. Department of Agriculture: Forest Service -National Agroforestry Center at DigitalCommons@University of Nebraska - Lincoln. It has been accepted for inclusion in USDA Forest Service / UNL Faculty Publications by an authorized administrator of DigitalCommons@University of Nebraska - Lincoln. 


\title{
REVIEW
}

\section{Blister rusts in China: hosts, pathogens, and management}

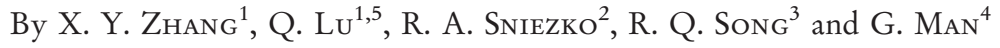 \\ ${ }^{1}$ Research Institute of Forest Ecology, Environment and Protection, Chinese Academy of Forestry, \\ Beijing, 10091, China; ${ }^{2}$ USDA Forest Service, Dorena Genetic Resource Center, Cottage Grove, OR \\ 97424, USA; ${ }^{3}$ Northeast Forestry University, Harbin, Heilongjiang, 150040, China; ${ }^{4}$ USDA Forest \\ Service, Forest Health Protection, Washington DC, USA; \\ ${ }^{5}$ E-mail: luquan@caf.ac.cn (for correspondence)
}

\begin{abstract}
Summary
China has 12 taxa of white pines (subgenus Strobus), including species of wide distribution valuable to plantation forestry and species of rare endemics only distantly related to other white pines. The most important forest diseases of these white pines are caused by the blister rust fungi of the genus Cronartium that alternate to telial host species of Ribes and Pedicularis. The most serious infestations have occurred in southwestern China on Pinus armandii and in northeastern China on P. koraiensis. The blister rust pathogen on $P$. armandii has usually been identified as Cronartium ribicola. Several lines of evidence, however, imply this pathogen on $P$. armandii is different from a pathogen on P. koraiensis that appears more closely related to C. ribicola in North America, Europe, and other Asian countries. In China, C. ribicola is designated as a quarantine pest. Silvicultural control of blister rust relies on pruning and thinning infected trees, herbicide removal of telial hosts, and chemical treatment of blister rust cankers. Although plantation forestry is important in China, little information is available on the genetics of resistance in Chinese white pines to native blister rust fungi. Challenges and opportunities are identified in forest management and research for disease assessment and control, rust systematics and biology, and genetic interactions in the white pine blister rust pathosystem.
\end{abstract}

\section{Introduction}

White pine blister rust caused by the pathogen Cronartium ribicola J.C. Fisch. in Rabh. infests populations of white pines (Pinus, subgenus Strobus) throughout the world to varying degrees (Geils et al. 2010; Kim et al. 2010; LA 2009). In North America, all 11 native white pine species are susceptible (BIngham 1972; Hoff et al. 1980; ТомвасK and Achuff 2010; : Table 1). Until the last few decades, Asian species of white pines were generally considered to be highly resistant to blister rust and only rarely infected in either natural stands or forest plantations. Recent reports from China, however, indicate that several species of white pine-particularly Pinus armandii Franch. and P. koraiensis Siebold \& Zucc.- - are quite susceptible to blister rust and that in some stands $>50 \%$ of the trees were infected (SAHO 1984; ZHAO et al. 1991).

In this review, we summarize information on the taxonomy, distribution, and status of white pines in China. For the blister rust fungi of China, we review and synthesize their history, hosts, distribution, diversity, disease severity, silvicultural management, and genetics. We conclude by identifying the principal challenges and opportunities presented by the white pine blister rust pathosystem to forest management and research in China. 


\section{White pines}

Twelve Pinus taxa of the subgenus Strobus comprise the white pines native to China (Fu and Hong 2000a; Wang and Hong 2004; Zheng 1983). As a group, the white pines occur widely across China, although some species have small populations and geographically limited native distributions (Fig. 1). Several species, however, have considerable populations and distributions that extend across large areas of eastern Asia (see KIm et al. 2010).

PRICE et al. (1998) assigned one taxa of the Chinese white pines to section Parrya and the remaining to section Strobus of which eight taxa are in the subsection Strobi and three taxa are in the subsection Cembrae. Pinus squamata Li is only distantly related to the other pines of section Parrya which also includes the North American Balfouriana (foxtail pines) and Cembroides (pinyon pines) (GERnANDT et al. 2005; Syring et al. 2007). The Chinese Strobi pines are closely related to P. strobus L. and many other white pines of western North America. The native Strobi pines of China are $P$. armandii var. armandii, $P$. armandii var. mastersiana (Hayata) Hayata, $P$. dabeshanensis Cheng \& Law, $P$. fenzeliana Handel-Mazzetti, $P$. kwangtungensis Chen (here segregated from $P$. fenzeliana), P. morrisonicola Hayata, $P$. wallichiana A.B. Jackson, and $P$. wangii $\mathrm{Hu} \&$

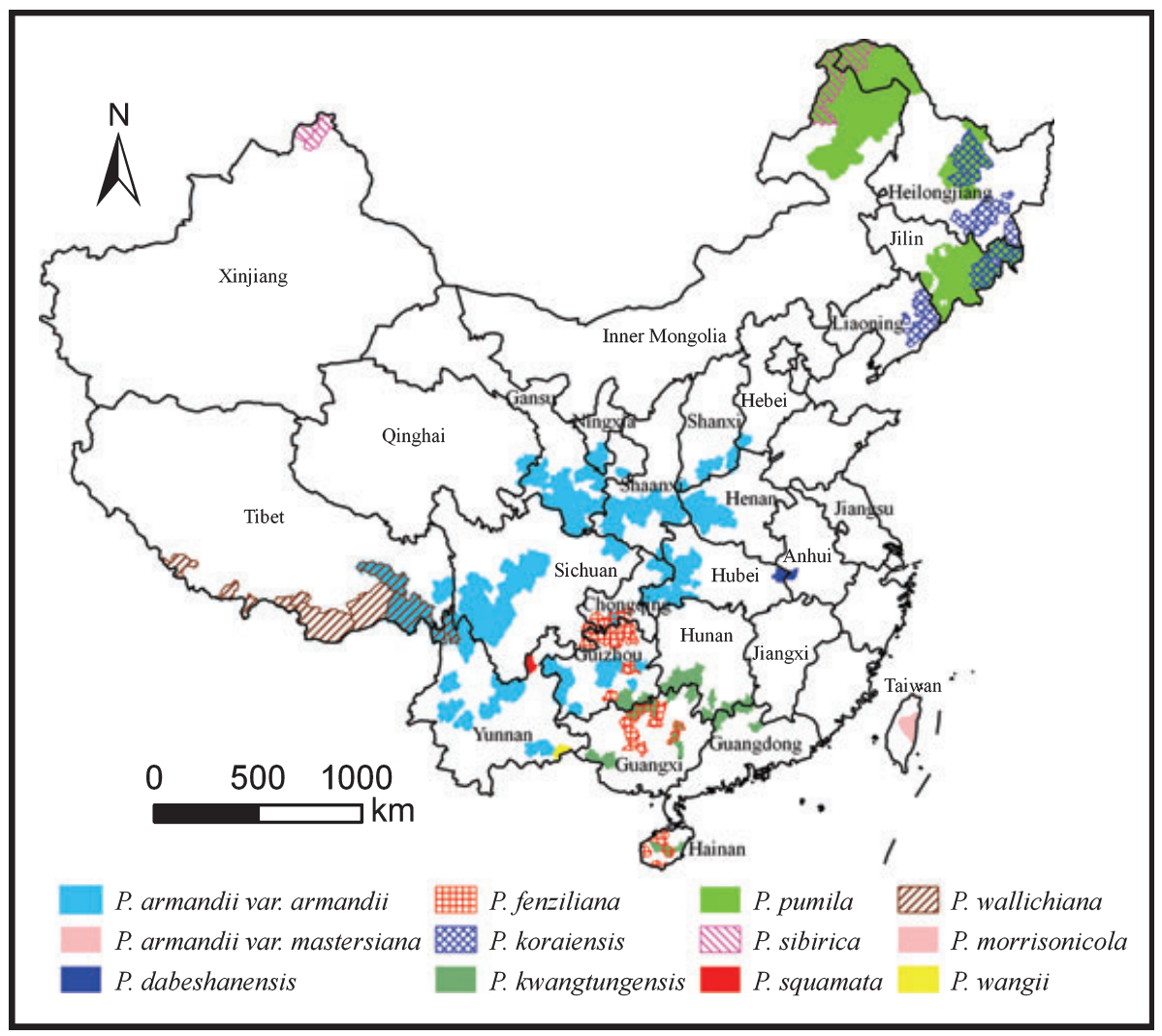

Fig. 1. General ranges for 12 taxa of white pines (subgenus Strobus) in China. 
Cheng. The native Chinese Cembrae (stone pines) are $P$. koraiensis, $P$. pumila Regel, and $P$. sibirica Du Tour; other stone pines occur in Europe and North America.

The white pines of China include species of value for economic commodities and ecosystem services and rare species of special conservation concern. $P$. armandii and $P$. koraiensis are the most widely distributed (Fig. 1) and important white pine species in eastern Asia. P. armandii occurs in 14 provinces of southwestern China. It ranges from subtropical to temperate regions at elevations from 1000 to $3300 \mathrm{~m}$. This Chinese white pine is widely planted for forestry, landscaping, and erosion control. P. koraiensis occurs in northeastern China, Korea, Japan, and the Russian Far East; it ranges in elevation from 150 to $1800 \mathrm{~m}$. This stone pine is a major forestry species planted in China and other regions of northeastern Asia. Only 32 individuals of $P$. squamata are known to exist in natural forests (Zhang et al. 2003). The IUCN Red List rates $P$. squamata as critically endangered, $P$. wangii as endangered, and $P$. dabeshanensis as vulnerable (INTERNATIONAL UNION FOR Conservation of Nature, 2007).

Although many species of fungi and insects are considered forest pests in China, significant tree losses and resource impacts are attributed to only a few of these (CHEN et al. 2007; Wang and Hong 2004). The most damaging insect is Dendroctonus armandi Tsai \& Li. which occurs in western and central China and typically attacks $P$. armandii. In the Qinling Mountains of Shaanxi province, this bark beetle causes extensive mortality to trees over 30 years old (CHen et al. 2007). The important pine diseases include blister and gall rusts caused by fungi of the genus Cronartium. The most prevalent and damaging rusts occur on the five most common white pines, namely $P$. armandii, $P$. koraiensis, $P$. wallichiana, $P$. pumila, and $P$. sibirica. Blister rust susceptibility and severity for the other Chinese white pines are poorly known.

\section{Cronartium rusts of pine}

The stem rust diseases on Chinese pines are simply described as white pine blister rust, pine blister rust, and Asian pine gall rust. The taxonomy and biology of the Cronartium rust fungi that cause these diseases, however, are unresolved, complex, and confused. Blister rust of the pines in subgenus Strobus has been principally attributed to C. ribicola, but a different pathogen has been implicated as causing blister rust on $P$. armandii. Other rust fungi infect Chinese pines of the subgenus Pinus (Tong 1979; Li and ReN 1984; LiU and Teng 1986; Xue et al. 1995, 1995; Song 2003). Cronartium flaccidum (Alb. \& Schwein.) G. Winter (pine blister rust) has a Eurasian distribution, broad ranges of aecial and telial hosts, and macrocyclic or microcyclic forms (KIM 2009). In China, pine blister rust occurs on $P$. densiflora Siebold \& Zucc., P. massoniana Lamb., P. sylvestris L., P. tabuliformis Carrière, and P. taiwanensis Hayata. (SHAO and Ju 1979; Ju et al. 1984; SHI 1984; JING et al. 1985; JING and WANG 1988a; b). Cronartium orientale Kaneko refers to the Asian pine gall rust segregated by Kaneko (2000) from C. quercuum (Berk.) Miyabe ex Shirai (endemic to North America). In China, the Asian pine gall rust occurs on native and introduced pines, including-Pinus banksiana Lamb., P. densiflora, P. densiflora subsp. takahasii (Nakai) Silba, P. echinata Mill., P. elliottii Engelm., P. massoniana, P. nigra Arnold, P. sylvestris, P. tabuliformis, $P$. taiwanensis, $P$. virginiana Mill., and P. yunnanensis Franch. (SHAO and Ju 1979; Xue et al. 1988, 1990a,b). The Asian pine gall rust alternates to telial hosts in the genus Quercus (oaks).

\subsection{White pine blister rust history and hosts}

The oldest report of C. ribicola in China (known to us) is a collection from 1900 on Ribes that is deposited in the herbarium of the New York Botanic Garden (CLInton 1919). In 1934, Hashioka made a collection of Cronartium uredinia and telia from Ribes formosanum 
Hayata at Mountain Xin'gao, Taiwan (Hiratsuka 1979). In 1940, Hiratsuka collected telia of C. ribicola from $R$. manshuricum (Maxim.) Kom. at Xiaoxing'an Mountain, Heilongjiang province (Hiratsuka 1941, 1979; TAI 1979).

The telial hosts of C. ribicola now reported for China include species in the genus Ribes (family Grossulariaceae) and the genus Pedicularis (family Orobanchaceae). The Chinese flora has 59 species and 30 varieties of Ribes (Fu and Hong 2000b) and 352 species, 109 subspecies, and 41 varieties of Pedicularis (Fu and Hong 2000c). Although additional species of Ribes and Pedicularis likely serve as telial hosts, only eight species of Ribes and three species of Pedicularis are reported. The telial hosts associated with the blister rust pathogen of $P$. armandii are Ribes glaciale Wall., $R$. tenue Jancz., $R$. giraldii Jancz., and $R$. takare D. Don (Li et al. 2007a; YANG 2003; YANG and Jin 1991). The confirmed telial hosts of C. ribicola associated with $P$. koraiensis in China are $R$. manshuricum, $R$. nigrum L., $R$. panciflorum Turcz. ex Ledeb., Pedicularis resupinata L., Pe. spicata Pall., and Pe. verticillata L. (Research group of pine blister rust, Heilongjiang 1979; Shao 1980; Shi 1985, 1991).

White pine blister rusts occur in China throughout the distributions of $P$. armandii, $P$. koraiensis, $P$. pumila, $P$. sibirica, and $P$. wallichiana (Fig. 1). Blister rust fungi have been found on $P$. armandii in southern China (Tibet, Yunnan, and Sichuan) and in central China (Chongqing, Hubei, Henan, Shanxi, Shaanxi, and Gausu). The stone pines of northern China infected by C. ribicola are $P$. koraiensis (Heilongjiang, Jilin, and Liaoning), $P$. pumila (Heilongjiang and Jilin), and P. sibirica (Xinjiang). A white pine blister rust referred to as C. ribicola occurs on $P$. wallichiana (Yunnan and Tibet).

Blister rust is a severely damaging disease of white pines in natural forests and plantations in two distant regions of China. In southwestern China (Shaanxi, Sichuan, Yunnan, and Tibet), blister rust is a problem principally on $P$. armandii but also on P. wallichiana (ZHAN 1979). Two thousand kilometres to the northeast (Heilongjiang, Jilin, and Liaoning), blister rust seriously impacts the forestry of $P$. koraiensis (RESEARCH GROUP OF PINE Blister RUST, HeilongJiang 1979).

Since 1982, blister rust has damaged $>50 \%$ of $P$. armandii trees in some areas (ZHAO et al. 1991). Infestations have occurred in the Qinling Mountains (Shaanxi) and in Sichuan province (Jing et al. 1986; YANG and Jin 1991; ZHAO et al. 1991). In Yunnan province, approximately 6000 ha of $P$. armandii forest were infested; rust incidence was typically $\sim 10 \%$ of trees infected but $>75 \%$ in some stands (FENG 2001). Approximately $10 \%$ of infected trees died from blister rust (YANG and ZHOU 1998). Incidence rates were higher in plantations than in natural stands, in plantations of single species than plantations of mixed species, and higher on sites with greater telial host density (JiA et al. 2000; WANG et al. 1996; YANG et al. 1996; ZhaO et al. 1991).

In 1956, an infestation of C. ribicola was discovered on P. koraiensis in Liaoning province (RESEARCH GROUP OF PINE BLISTER RUST, HeIlongjiang 1979). The rust incidence increased from $8 \%$ in 1956 to $25 \%$ in 1959 to $60 \%$ in 1975 ; eventually, $40 \%$ of infected trees died (SAHO 1984). Twenty years later, C. ribicola was prevalent in most plantations of $P$. koraiensis in Heilongjiang, Liaoning, and Jilin provinces (Fig. 2). Total incidence in five sampled stands was $40 \%$ (48\% maximum) (RESEARCH GROUP OF PINE BLISTER RUST, HEILONGJIANG 1979).

The geographic origin and genetic diversity of the white pine blister rust fungi in China are unknown. The apparently recent increase in blister rust incidence and difference in behaviour may be explained by two hypotheses: (1) an exotic invasive pathogen was introduced (Hiratsuka 1995a; Cheng et al. 1997, 1998b); and (2) a native pathogen escaped notice until it emerged as a serious problem with the advent of plantation forestry or some other environmental change in the climate or vegetation. 


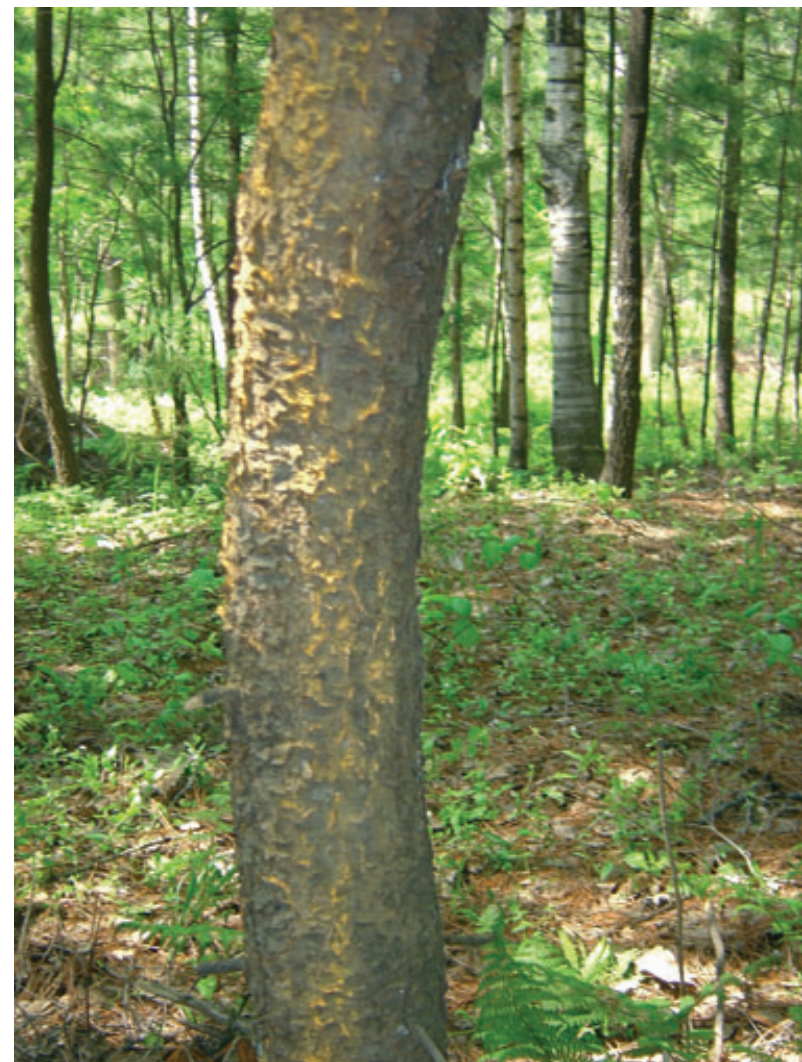

Fig. 2. Pinus koraiensis in northeastern China with large blister rust canker caused by an active infection of Cronartium ribicola. Such a large area of sporulation may not be typical of C. ribicola, but it opens a question whether this might actually indicate host tolerance whereby sporulation develops near the surface of the inner bark (phloem). Photo courtesy of Hongshi Forestry Bureau, Jilin province, China.

\subsection{Cronartium diversity in China}

\subsubsection{Stem rusts of pine}

Comparisons of DNA from the recognized species of Cronartium in China provide a useful reference for examining the diversity of the blister rust fungi on white pines. Cheng et al. (1998a) used random amplified polymorphic DNA (RAPD) to assess genetic differentiation among Chinese isolates identified as C. ribicola, C. flaccidum, and C. quercuum ( $=$ C. orientale). Although intraspecific variation was present, the rust fungi clearly segregated into distinct groups conforming with the traditional taxonomy. Genetic relatedness between C. ribicola and C. flaccidum was closer than that between C. quercuum and either of the other two. These observations were consistent with expectations based on disease type (blister rust or gall rust) and telial host range (Pedicularis common to C. ribicola and C. flaccidum or Quercus). Hou (2002) and HeI et al. (2003) sequenced internal transcribed space (ITS) regions of Chinese isolates 
identified as C. ribicola, C. flaccidum, and C. quercuum (= C. orientale) and constructed phylogenetic trees using these sequences and other sequences from GenBank. The resulting phylogenetic trees consistently showed four distinct Chinese clades - one each for C. flaccidum and C. quercuum and two for C. ribicola (discussed below). The Chinese isolates of C. flaccidum and C. quercuum clustered together with respective reference sequences from GenBank and supported previous results using isozyme and RAPD analyses (CHENG et al. 1997, 1998a).

\subsubsection{Blister rusts of white pine}

Data on host range, aeciospore morphology, proteins, and DNA indicate the Cronartium that infects $P$. armandii in southern China and the Cronartium that infects $P$. koraiensis in northeastern China form different populations. Whether the differences are sufficient for these pathogens to be recognized as biotypes (races or special forms) or as taxa (varieties, subspecies, or species) has not been resolved.

Cronartium isolated from $P$. armandii can only alternate to species of Ribes (LI et al. 2007a; YANG 2003; YANG and JIN 1991), whereas the Cronartium from P. koraiensis can alternate to species of either Ribes or Pedicularis (RESEARCH GROUP OF PINE BLISTER RUST, Heilongjiang 1979; Shao 1980; Shi 1985, 1991). Based on this host specialization, Yang and Jin (1991) proposed C. ribicola f. sp. ribicola as the name of the rust on $P$. armandii; but this designation is not widely accepted.

LI et al. (2007b) compared aeciospores from infected P. armandii collected in Yunnan, Sichuan, and Shanxi provinces with aeciospores from infected P. koraiensis collected in Liaoning province. The distance separating the farthest samples from $P$. armandii was $1000 \mathrm{~km}$; another $1000 \mathrm{~km}$ separated infected $P$. armandii from the nearest infected $P$. koraiensis. Aeciospores of the rust on $P$. armandii were significantly larger than those collected on $P$. koraiensis. The warts on aeciospores from $P$. armandii were wider at the base than the top, whereas the warts on aeciospores from $P$. koraiensis were uniform in width at the base and the top.

Cheng et al. (1997, 1998b)) found similar isozyme patterns for all the Cronartium isolates they collected from $P$. koraiensis in northeastern China. This expression of limited genetic variation suggested there was a high degree of genetic homogeneity within the pathogen population on $P$. koraiensis. This similarity could have been caused by a founder effect as result of either recent introduction or emergence from a population bottleneck.

The ITS sequences and phylogenic trees constructed by Hou (2002) and HeI et al. (2003) consistently supported the Cronartium clade from $P$. armandii (Sichuan) as distantly related to the clade from $P$. koraiensis (Liaoning). Compared with reference sequences from GenBank, the Cronartium from $P$. armandii formed an isolated clade more closely related to a $C$. flaccidum clade than a C. ribicola clade, whereas the Cronartium from $P$. koraiensis grouped together with references sequences of C. ribicola (also see RichaRdson et al. 2010; Fig 1).

Li et al. (2008) used random amplified microsatellite (RAMS) markers to assess genetic diversity in seven Cronartium populations-three infesting $P$. armandii in southwestern China and four infesting $P$. koraiensis in northeastern China. The genetic diversity among populations from different host species and regions was higher than that from the same host species and region. Dendrogram analysis based on Nei's genetic distance showed that the Cronartium on $P$. armandii formed an isolated branch from the Cronartium on $P$. koraiensis. High genetic distance value between the two groups indicated significant heterogeneity in the Chinese Cronartium and implied the Cronartium on P. armandii was different from C. ribicola. 


\section{Management}

\subsection{Quarantine and silviculture}

Cronartium ribicola is a quarantine pest in China, therefore import or export of blister rustinfected nursery stock is prohibited (Zeng 1988; Asia Pacific Seed Association, 2007). SoNG (1988) conducted a risk assessment and defined four quarantine zones based on the distributions of C. ribicola and susceptible white pines and the positions of May and September $20^{\circ} \mathrm{C}$ isotherms. These quarantine zones are identified by host species and province as: (1) P. sibirica in Xinjiang; (2) P. koraiensis in Heilongjiang, Jilin, and Liaoning; (3) $P$. armandii in Shaanxi, Gansu, Sichuan, Hubei; and (4) P. armandii in Yunnan. Quarantine restricts transfer of seedlings outside of these areas and thus should limit the movement of blister rust fungi (and their genes) into regions where they might become invasive.

A variety of silvicultural measures have been evaluated at the levels of individual trees and plantations for blister rust control in China (also see OsTry et al. 2010; ZEgLEN et al. 2010). Investigations have examined use of: (1) pruning and thinning infected pines; (2) herbicides on telial hosts (Research group of PINe blister rust, HeIlongjiang 1979); (3) fungicides on cankers (Ju et al. 1984; RESEARCH GROUP OF PINE BLISTER RUST, Heilongjiang 1979; Wang 1984; Wang et al. 1996; YAng et al. 1997; Zhong et al. 1990); (4) laser irradiation of cankers (WeI et al. 1982); and (5) biological control (CHEN et al. 2006; MA et al. 2002; YANG and ZHOU 1998; YANG et al. 2005). Although all these techniques have shown some effectiveness, laser irradiation, and biological control have only been assessed on limited scales. Sanitation pruning, herbicide eradication of telial hosts, and chemical treatment of cankers are routinely used to reduce damage in Chinese white pine plantations; but few data are available to quantify their long-term efficacy in China. Herbicides and chemical treatments are rarely used in North America (ZEgLeN et al. 2010).

Efforts at widespread eradication of invasive pathogens impacting valuable forest plantations have meet with mixed success. In South Korea, a long-term, country-wide programme of sanitation and Pedicularis control reduced blister rust incidence throughout the country (KIm et al. 2010; LA 2009). In North America, Ribes eradication for blister rust control was a large programme continued for many decades (GeIls et al. 2010). Although removing Ribes bushes within control areas reduced blister rust infection locally and temporarily, mechanical and chemical eradication of Ribes at a landscape-level was unsustainable and discontinued. In China, various silvicultural techniques have reduced blister rust impacts in treated plantations, but these activities have not eliminated blister rust from the country. Cronartium ribicola is a permanent resident of many white pine forests in China; continued vigilance and persistence with quarantines and silviculture management can contribute to the protection of white pine resources.

\subsection{Genetics}

A long-term approach for reducing blister rust impacts in China would be to increase the frequency of genetically inherited resistance in populations of white pines at risk. Whether white pines are naturally regenerated in native stands or artificially propagated for plantations, an understanding of genetics and tree improvement would complement silvicultural management. There is evidence in the Asian white pines for resistance to native blister rust fungi, but most genetic studies that included Asian species have been conducted in Europe or North America with isolates of C. ribicola found there (see KING et al. 2010). The diversity of blister rust pathosystems and different environments occurring in China complicate genetics research and its application.

Several observations on Cronartium $-P$. armandii interactions provide clues to escape, tolerance, and resistance in this pathosystem. Meng et al. (2006) examined needles of 
$P$. armandii exposed by artificial inoculation to blister rust basidiospores. Needles that putatively escaped infection always had thicker keratose membranes and epidermal cell walls than needles that became infected. Some $P$. armandii trees in Sichuan province appear to tolerate large basal cankers (R. Sniezko, pers. comm.). A hypersensitive needle reaction similar to the R-gene resistance response of other white pines developed in $P$. armandii and P. morrisonicola inoculated with North American isolates of C. ribicola (Hoff and McDonald 1975; Lu et al. 2005; SNiezko et al. 2008).

Little information is available for most Asian white pines on their genetic resistance to native blister rust fungi. No field trials have been conducted in China to assess species or family-level differences in resistance, and trials in other counties have not used inoculum from China. The few studies conducted outside of China have provided much of what is known about resistance in the Asian white pines (Hoff et al. 1980; McDonald and Hoff 1971). Although Asian white pines challenged with C. ribicola from North America or Europe showed high levels of resistance, many Chinese plantations have been severely infested. This difference in behaviour may be explained by three possibilities: (1) gene-by-environment interactions; (2) presence in China of virulent or aggressive pathogens; or (3) planting on sites environmentally favourable for severe infestation (high hazard). Genetic resistance in Chinese white pines to endemic blister rust fungi, however, should be expected since resistance occurs in the North American white pine only recently exposed to the introduced C. ribicola (Bingham 1983; Kinloch 2003). The distribution and diversity of white pines and blister rust fungi in China suggest there could be significant regional variations in population genetics, mechanisms of resistance, and rust hazard.

\section{Challenges and opportunities}

Forest management in China is challenged with the infestation and mortality of diverse native white pines by several blister rust fungi. Historically, blister rust was not a concern in native stands; but recent losses in plantations of $P$. armandii and $P$. koraiensis were sufficient to require silvicultural intervention. An assessment of blister rust impacts, review of strategies, and further development of methods could help align silvicultural practice with management objectives and constraints. Although blister rusts on $P$. armandii and on $P$. koraiensis have both been attributed to C. ribicola, differences between the fungi on these hosts appear to be significant. Research on Cronartium phylogeny, systematics, and genetics could provide a foundation for managing white pine blister rust pathosystems. Programmes in other countries have advanced an understanding of resistance to blister rust; but little is known about the resistance of Chinese white pines to native blister rust fungi. Basic and applied research on the distribution, mechanisms, and inheritance of resistance could support Chinese forestry with information and improved planting stock useful for regenerating natural stands and establishing plantations.

\subsection{Forest management}

Plantations of white pines in China have required labour-intensive treatments of sanitation and eradication to protect trees and reduce infection rates. As forest plantations are established in the future, continued planting of white pine and reliance on silviculture present several risks. One option would be to abandon white pine forestry on some sites. Although this may be a practical alternative to planting on high hazard sites, blister rust left unmanaged would threaten native populations and species. Furthermore, white pines are often the best adapted species for many sites; and replacement species have their own liabilities (Harvey et al. 2008; Schwandt et al. 2010). Global climate change and unusual weather add to the uncertainty of managing Chinese white pine forests and plantations. 
Several management and research activities could help determine effective strategies for white pine forestry in China. Quantitative assessments could be prepared on the economic and ecological impacts and risks from blister rust by region, host, and policy alternative. Rust hazard could be projected for potential planting sites. Further development and evaluation of silvicultural techniques, especially chemical and biological controls, could be conducted. To better track infestations and treatment effectiveness, monitoring procedures could be established.

\subsection{Systematics and pathology}

Several concerns arise from the diversity of white pine blister rust pathosystems in China. A pathogen introduced to a new region or country might display novel virulence or increased aggressiveness compared with an endemic or naturalized pathogen. Little is known about the pathogenicity and epidemiology of blister rust fungi on the Chinese white pine species that are rare, have apparently escaped infestation, or display variation in resistance.

Studies into the evolution and biology of the Chinese Cronartium infecting white pines could provide useful information for assessing their likely behaviour on various hosts and in different regions. Priority research could be conducted to elucidate the taxonomy of the pathogen on $P$. armandii and to compare the morphology, ecology, and molecular biology of the blister rust fungi on $P$. pumila, $P$. sibirica, and $P$. wallichiana with those on $P$. armandii and $P$. koraiensis. DNA analyses and cross-inoculations using isolates from geographically distant sources could be performed to obtain information on rust biogeography, genetic variation, and gene-by-environment interactions. This information would serve to reinforce current quarantines, provide data for refining quarantine measures, and provide insights useful for advancing resistance programmes in various countries.

\subsection{Genetic resistance}

The co-evolutionary interactions of the Cronartium rust fungi and their hosts are important dynamics affecting the long-term future of white pine populations in China. Although little information is available from Chinese studies on the genetics of blister rust resistance, the concepts, techniques, and results of work in other counties are available (King et al. 2010; Richardson et al. 2010). In Canada and the United States, enhancing and deploying genetic resistance are key elements in their national strategies for mitigating the impacts of white pine blister rust. China and several other Asian counties share in common several white pine species and blister rust fungi. International scientific collaboration provides numerous mutual benefits.

Studies could be conducted on the distribution, mechanisms, and inheritance of resistance in Chinese white pines. A genetic survey of white pines with samples collected across the distributions of each species could provide baseline data on the frequencies and spatial patterns of resistance traits associated with different Cronartium rust fungi.

A complementary study in China to test resistant families from North American breeding programs as well as other species from Europe and Asia using blister rust variants from China would be very useful. Such a test could provide an early alert on the potential damage these variants could inflict elsewhere and potential information on the possible evolutionary potential of current variants of blister rust pathogen in North American and Europe. A first attempt at such a test was unsuccessful due to logistical constraints (R. Sniezko, pers. comm.), but there are no technical barriers preventing such investigation.

The various white pines could be inoculated with blister rust fungi to identify resistance traits (interaction phenotypes) and determine their inheritance. Candidate white pine could 
be screened for resistance and other adaptive traits and placed in field trials to assess their long-term performance. Investigations could characterize the molecular biology of putative $\mathrm{R}$ genes in the host and corresponding virulence genes in the pathogen. This basic research and its application would provide better adapted planting stock and useful information for managing white pine genetic resources. Given the capabilities of Chinese forestry research and management and the accompanying diversity of hosts and pathogens, investigations conducted in China would contribute much to test and refine ideas on resistance and virulence in white pine blister rust pathosystems.

\section{Acknowledgements}

We thank Brian Geils, Terry Shaw, and Angelia Kegley for suggestions and edits to earlier versions of this article, thank Feng Yiming for preparing the white pine distribution map. The first and second authors acknowledge the financial support from the Chinese fundamental scientific research fund special for state commonweal institutes (CAFRIF200705) and the state science and technology support plan program (2006BAD08A19).

\section{References}

Asia Pacific Seed Association, 2007: List of quarantine pests from imported plants issued by P.R. China. [Online]. Available : http: //www.apsaseed.org/docs/fe6b5b5c/pest_list_China.doc

Bingham, R.T., 1972: Taxonomy, crossability, and relative blister rust resistance of 5-needled white pines. In: Biology of rust resistance in forest trees: Proceedings NATO-IUFRO Advanced Study Institute, Moscow, ID, 1969 August 17-24. ED. By Bingham, R.T.; Hoff, R.J.; McDonald, G.I. Misc. Publ. 1221. Washington, DC: U.S. Department of Agriculture, Forest Service. pp. 271-280. [Online]. Available: http://www.treesearch.fs.fed.us/pubs/35041.

Bingham, R.T., 1983: Blister rust resistant western white pine for the Inland Empire: The story of the first 25 years of the research and development program. Gen. Tech. Rep. INT-146. Ogden, UT: U.S. Department of Agriculture, Forest Service, Intermountain Forest and Range Experiment Station. 45 p.

Chen, Y.H.; YAnG, Y.H.; Li, Y.H.; Lin, H.Y., 2006: Destructive effects of three Trichoderma spp. on the aeciospores of Cronartium ribicola. Plant Protection 33, 62-65.

Chen, L.G.; Xu, Z.H.; He, Z.P., 2007: Research advances on insect pests of Pinus armandii. Journal of Southwest Forestry College 27, 47-52.

Cheng, D.-S.; Han, X.Y.; XUE, Y; Pan, X.R.; LI, W.H., 1997: Isozymic variation among and within species of pine-stem rust fungi in China. Scientia Silvae Sinicae 33, 330-337.

Cheng, D.-S.; Liang, H.Y.; Xue, Y.; Pan, X.R.; Li, W.H., 1998a: Genetic differentiation among three pine-stem rust fungi from China as estimated by random amplification polymorphic DNA. Scientia Silvae Sinicae 34, 53-60.

Cheng, D.-S.; Xue, Y.; Pan, X.R.; Li, W.H., 1998b: Population genetic structures of three Cronartium species from China based upon allozyme analysis. Mycosystema 17, 32-39.

Clinton, G.P., 1919: Inspection of phaenogamic herbaria for rusts on Ribes spp. Bull. 214. New Haven, CT: Connecticut Agricultural Experiment Station. pp. 423-427.

FENG, S.M., 2001: Occurrence and risk evaluations of selected pests of forest plant quarantine significance in Yunnan province. Forest Pest and Disease 4, 31-33.

Fu, L.G.; Hong, T., eds., 2000a: Pines. In: Higher Plants of China. Ed. By Fu, L.G.; Chen, T.Q.; Liang, K.Y.; Hong, T. Qingdao: Qingdao Publishing House. pp. 54-58.

Fu, L.G.; Hong, T., eds., 2000b: Grossulariaceae. In: Higher Plants of China. Ed. By Fu, L.G.; Chen, T.Q.; Liang, K.Y.; Hong, T.; Lin, Q.; LI, Y. Qingdao: Qingdao Publishing House. pp. 294-318.

Fu, L.G.; Hong, T., eds., 2000c: Pedicularis. In: Higher Plants of China. Ed. By Fu, L.G.; Chen, T.Q.; Liang, K.Y.; Hong, T.; Lin, Q.; LI, Y. Qingdao: Qingdao Publishing House. pp. 180-222.

Geils, B.W.; Hummer, K.E.; Hunt, R.S., 2010: White pines, Ribes, and blister rust: a review and synthesis. For. Pathol. 40, 147-185.

Gernandt, D.S.; López, G.G.; García, O. S.; Liston, A., 2005: Phylogeny and classification of Pinus. Taxon 54, 29-42. [Online]. Available: http://www.jstor.org/stable/25065300

Harvey, A.E.; Byler, J.W.; McDonald, G.I.; Neuenschwander, L.F.; Tonn, J.R., 2008: Death of an ecosystem: Perspectives on western white pine ecosystems of North America at the end of the twentieth century. Gen. Tech. Rep. GTR-208. Fort Collins, CO: U.S. Department of Agriculture, 
Forest Service, Rocky Mountain Research Station. 10 p. [Online]. Available: http://www.treesearch.fs.fed.us/pubs/29617

Hei, W. [sic He]; Hou, L.-B.; Liu, X.-Y.; YANG, Z.-Z. 2003: The ITS region sequence analysis of Chinese pine stem rusts. In: 2nd IUFRO Rusts of Forest Trees Working Party Conference, Yanglin, China, 2002 August 19-23. Ed. By Xu, M.-Q.; Walla, J.A.; ZhaO, W.-X. For. Res. 16 (Suppl.). Beijing, China: Chinese Academy of Forestry. pp. 146-152.

Hiratsuka, N., 1941: Materials for a rust flora of Manchoukuo. I. Transactions of the Sappro Natural History Society 16, 193-208.

Hiratsuka, N., 1979: A topic on the white pine blister rust. Forest Pest 6, 2-6.

Hiratsuka, Y., 1995a: Pine stem rusts of the world-Frame work for a monograph. In: 4th IUFRO Rusts of Pines Working Party Conference, Tsukuba, Japan, 1994 October 2-7. Ed. by Kaneko, S.; Katsuya, K.; Kakishima, M.; Ono, Y. Kukizaki, Japan: Forestry and Forest Products Research Institute, Forest Microbiology Section. pp. 1-8.

Hoff, R.J.; McDonald, G.I., 1975: Hypersensitive reaction in Pinus armandii caused by Cronartium ribicola. Can. J For. Res. 5, 146-148. [Online]. doi: 10.1139/x75-020

Hoff, R.J.; Bingham, R.T.; McDonald, G.I., 1980: Relative blister rust resistance of white pines. Euro. J For. Path. 10, 307-316. [Online]. doi: 10.1111/j.1439-0329.1980.tb00042.x

Hou, L.B., 2002: The RAPD and sequences of ITS region analysis of Chinese strains of pine stem rust. Beijing, China: Beijing Forestry University. Thesis.

Hummer, K.E.; Dale, A., 2010: Horticulture of Ribes. For. Pathol. 40, 251-263.

International Union for Conservation of Nature, 2007: Conifer Specialist Group 1998. Pinus wangii. IUCN Red List of Threatened Species. [Online]. Available: http://www.iucnredlist.org

Jia, Y.; Chen, Z.; Zhang, L.; Yu, J.; Wang, Y.; He, R., 2000: The survey and study on Cronartium ribicola to Korean pine plantations. Journal of Northeast Forestry University 28, 43-47.

Jing, Y.; WANG, P.X., 1988a: A study on the blister rust massoniana pine and its alternative host. Acta Mycologica Sinica 7, 112-115.

Jing, Y.; Wang, P.X.; Chen, H.; Chen, Y.M., 1985: A preliminary investigation on the blister rust of Pinus massoniana. Forestry Sci-Tec Newsletter 12, 23-26.

Jing, Y.; Zhang, X.Y.; Lu, Y.B., 1986: Preliminary report of the study on Pinus armandii blister rust. Shaanxi Forest Science and Technology 1, 30-35.

Ju, G.Z.; He, B.Z.; Yin, C.C.; Zhang, Y.Q.; Li, C.L., 1984: A study on the blister rust of Pinus sylvestris var. mongolica. Scientia Silvae Sinicae 20, 149-155.

KAnEKo, S., 2000: Cronartium orientale, sp. nov., segregation of the pine gall rust in eastern Asia from Cronartium quercuum. Mycoscience 41, 115-122. [Online]. doi: 10.1007/BF02464319

Kim, M.-S., Chair 2009: Recovery plan for Scots pine blister rust. March 12, 2009. Washington, DC: U.S. Department of Agriculture, Agriculture Research Service, Office of Pest Management National Plant Disease Recovery System. 23 p. [Online]. Available: http://www.ars.usda.gov/ research/docs.htm?docid $=14271$

Kim, M.-S.; Klopfenstein, N.B.; Ota, Y.; Lee, S.K.; Woo, K.-S.; Kaneko, S., 2010: White pine blister rust in Korea, Japan, and other Asian regions: Comparisons and implications for North America. For. Pathol. 40, 382-401.

King, J.N.; David, A.; Noshad, D.; Smith, J., 2010: A review of genetic approaches to the management of blister rust in white pines. For. Path. 40, 292-313.

Kinloch, B.B., JR., 2003: White pine blister rust in North American: Past and prognosis. Phytopathology 93, 1044-1047. [Online]. doi: 10.1094/PHYTO.2003.93.8.1044

LA, Y.-J., 2009: Korean successes in controlling blister rust of Korean pine. In: Breeding and Genetic Resources of Five-Needle Pines Conference, Yangyang, Republic of Korea, 2008 September 22-26. Ed. By Noshad, D.; Noh, E.; King, J.; Sniezko, R. Yangyang: Korea Forest Research Institute. pp. 1-9.

LI, L.G.; He, P.; He, W., 2008: Genetic diversity of five-needle pine blister rust detected by random amplified microsatellite (RAMS) in China. Journal of Beijing Forestry University 30, 112-118.

LI, X.S.; ReN, G.L., 1984: Identification of blister rusts of three pine species in Henan province with a scanning electron microscope. Journal of Henan Agricultural College 2, 89-93.

LI, Y.H.; Ye, H.; Zhou, X.G., 2007a: A study on pathogenic specialization of Cronartium ribicola. Journal of West China Forestry Science 36, 13-16.

LI, Y.H.; ZHou, X.G.; Ye, H., 2007b: A study on the morphological differentiation of aeciospores of Cronartium ribicola. Journal of Sichuan Forestry Science and Technology 28, 6-9.

Liu, S.-C.; Teng, H.-M., 1986: Aeciospores surface morphology of pine blister rusts of China as observed under a scanning electron microscope. Acta Mycologica Sinica 5, 7-9. 
Lu, P.; Sinclair, R.W.; Boult, T.J.; Blake, S.G., 2005: Seedling survival of Pinus strobus and its interspecific hybrids after artificial inoculation of Cronartium ribicola. For. Ecol. Manage. 214, 344-357. [Online]. doi: 10.1016/j.foreco.2005.04.024

Ma, J.P.; Yang, H.B.; Jin, Y.F.; Zhang, Q.S.; Yang, C.S., 2002: Technological research on comprehensive control of Pinus armandii blister rust in Yunnan. Journal of Southwest Forestry College 22, 47-49.

McDonald, G.I.; Hoff, R.J., 1971: Resistance to Cronartium ribicola in Pinus monticola: Genetic control of needle-spots-only resistance factors. Can. J For. Res. 1, 197-202. [Online]. doi: 10.1139/x71-026

MenG, J.F.; WanG, S.G.; Pu, X.L., 2006: The relation of the blister rust resistance and the structures of the needle epidermis in the Pinus armandii Franch. Journal of Central South Forestry University 26, 43-46.

Ostry, M.E.; Laflamme, G.; Katovich, S. A., 2010: Silvicultural approaches for management of eastern white pine to minimize impacts of damaging agents. For. Pathol. 40, 332-346.

Price, R.A.; Liston, A.; Strauss, S.H., 1998: Phylogeny and systematics of Pinus. In: Ecology and Biogeography of Pinus. Ed. By Richardson, D.M. Cambridge, UK: Cambridge University Press. pp. $49-68$.

Research GRoup of PINe Blister Rust, Heilongjiang, 1979: A study on blister rust of Korean pine. Scientia Silvae Sinicae 16, 119-124.

Richardson, B.A.; Ekramoddoulah, A.K.M.; Liu, J.-J.; Kim, M.-S., 2010: Current and future molecular approaches to investigate the white pine to minimize impacts of damaging. For. Pathol. 40, 226-250.

SАно, H., 1984: Inoculation and natural distribution of a pine-to-pine stem rust of white pines, Peridermium yamabense Saho et I. Takahashi. Report of the Tottori Mycological Institute of Japan 22, 102-107.

Schwandt, J.W.; Lockman, I.B.; Kliejunas, J.T.; Mulir, J.A., 2010: Current health issues and management strategies for white pines in the western United States and Canada. For. Pathol. 40, 226-250.

ShaO, L.P., 1980: The identification of pathogen of Korean pine blister rust. Scientia Silvae Sinicae 4, 279-282.

SHAO, L.P.; Ju, G.Z., 1979: Spore surface morphology of three pine blister rusts (Cronartium spp.) of China as observed under a scanning electron microscope. Journal of Northeastern Forestry Institute 2, 57-61.

SHI, F.Z., 1984: A study on the pathogen and the alternate hosts of blister rusts of Chinese pine and Japanese red pine. Acta Mycologica Sinica 3, 54-58.

SHI, F.Z., 1985: A study on alternative hosts of Korean blister rust pathogen. Liaoning Forestry Science and Technology 6, 30-31.

SHI, F.Z., 1991: A formae speciales of Cronartium ribicola. Forest Pest and Disease 1, 12-13.

Sniezko, R.A.; Kegley, A.; Danchok, R.; Schoettle, A.W.; Burns, K.A.; Conklin, D., 2008: Cronartium ribicola resistance in whitebark pine, southwestern white pine, limber pine and Rocky Mountain bristlecone pine. In: 55th Western International Forest Disease Work Conference, Sedona, AZ, 2007 October 15-19. Ed. By McWilliams, M.G. comp. Salem, OR: Oregon Department of Forestry. pp. 84-86.

Song, R.Q., 2003: Pine blister rust disease. In: Major forest diseases and insect pests in China. Ed. By Zhang, X.Y.; Luo, Y.Q. Beijing, China: Forestry Publishing House. pp. 277-290.

Song, Y.S., 1988: Potential suitability assessment of five needle pine blister rust in China. Forest Pest and Disease 2, 27-30.

Syring, J.; Farrell, K.; Businsky, R.; Cronn, R.; Liston, A., 2007: Widespread genealogical nonmonophyly in species of Pinus subgenus Strobus. Syst. Biol. 56, 163-181. [Online]. doi: $10.1080 / 10635150701258787$

TAI, F.L., 1979: Sylloge fungorum Sinicorum. Beijing: Science Publishing House. p. 441.

Tомваск, D.F; Achuff, P., 2010: Blister rust and western forest biodiversity: Ecology, values, and outlook for white pines. For. Path. 40, 186-225.

Tong, B.-Q., 1979: Surface structure of the spores of three Chinese pine stem rusts under scanning electron microscope. Forestry Science of China 15, 241-243.

WANG, X.G., 1984: Occurrence and control of Korean pine blister rust. Jilin Forest Science and Technology 4, 7-11.

WANG, H.R.; HonG, J.S., 2004: Genetic resources, tree improvement and gene conservation of fiveneedle pines in East Asia. In: Breeding and Genetic Resources of Five-needle Pines: Growth, Adaptability and Pest Resistance, IUFRO Working Party 2.02.15, Medford, OR, 2001 July 23-27. 
Ed. By Sniezko, R.A.; Samman, S.; Schlarbaum, S.E.; Kriebel, H.B. Proceedings RMRS-P-32. Fort Collins, CO: U.S. Department of Agriculture, Forest Service, Rocky Mountain Research Station. pp. 73-78. [Online]. Available: http://www.fs.fed.us/rm/pubs/rmrs_p032/rmrs_p032_ 073_078.pdf

WANG, H.L.; Dong, Y.; LI, G.X., 1996: Observation and study on Korean pine blister rust. Forest Science and Technology 21, 31-32.

WeI, Z.Q.; Huang, G.J.; Liu, F.Q.; Wang, Q.C.; Yuan, G.; Sun, J., 1982: Laser irradiation effect on restraining the germination of aeciospores of Cronartium ribicola. Liaoning Forestry Science and Technology 4, 29-31. [Online]. Available: http://www.apsaseed.org/docs/fe6b5b5c/pest_China.doc

Xue, Y.; Shao, L.P.; Jin, G.M.; Cui, Y.Z., 1995: Study on the histopathology of three pine stem rust disease. Journal of Northeast Forestry University 23, 1-7.

Xue, Y.; Shao, L.P.; Wang, Z.H., 1988: Histopathological analysis on gall rust of Pinus takahasii. Journal of Northeast Forestry University 16, 10-13.

Xue, Y.; ShaO, L.P.; Wang, Z.H., 1990a: Study on gall rust of Pinus takahasii. Journal of Northeast Forestry University 18, 38-47.

Xue, Y.; Shao, L.P.; Wang, Z.H., 1990b: Teliospore germination of Cronartium quercuum. Forest Pest and Disease 4, 30-31.

YANG, B.; Zhou, T.S., 1998: A study on Armand blister rust in Yunnan province. In: Proceedings of Key Laboratory for Plant Pathology in Yunnan Province. Ed. By Yu, S.P. Kunming: Yunnan Science and Technology Publishing House. pp. 295-305.

YANG, Y.-H.; Chen, Y.-H.; ZHu, Y.-F., 2005: Isolation and identification of Cronartium ribicola mycoparasites in southwest China. Journal of Zhejiang Forestry College 22, 414-419.

YANG, Z.-Z., 2003: Alternate host of Armand pine blister rust in China. In: 2nd IUFRO Rusts of Forest Trees Working Party Conference, Yanglin, China, 2002 August 19-23. Ed. By Xu, M.-Q.; Walla, J.A.; Zhao, W.-X. For. Res. 16(Suppl.). Beijing, China: Chinese Academy of Forestry. pp. 99-100.

YANG, Z.Z.; Jin, D.Q., 1991: A preliminary study on Pinus armandii blister rust and its alternate hosts. Forest Pest and Disease 3, 13-14.

YANG, Z.Z.; Jin, D.Q.; SU, A.Q.; LE, G.F.; WANG, X.W., 1996: Study on the regularity [phenology] of Armand pine blister rust. Journal of Sichuan Agricultural University 14, 247-252.

YAng, Z.Z.; Jin, D.Q.; Su, A.Q.; Le, G.F.; Wang, X.W., 1997: A study on integrated control technique of Pinus armandii blister rust. Forest Pest and Disease 1, 24-26.

Zeglen, S.; Pronos, J.; Merler, H., 2010: Silvicultural management of white pines in western North America. For. Pathol. 40, 347-368.

ZENG, D.P. 1988: Quarantine concern objects of trees and dangerous pests for importation to China. Beijing, China: China Forestry Publishing House. pp. 1-3.

Zhan, M.M., 1979: Preliminary analysis of the rust flora in the forest of Tibet. Scientia Silvae Sinicae $15,1-8$.

Zhang, Z.Y.; YAnG, J.B.; LI, D.Z., 2003: Phylogenetic relationship of an extremely endangered species, Pinus squamata (Pinaceae) inferred from four sequences of the chloroplast genome and ITS of the nuclear ribosomal DNA. Acta Botanica Sinica 45, 530-535.

Zhao, S.G.; Jing, Y.; Zhang, X.Y.; LI, J.Q., 1991: Distribution and damage of Armand pine blister rust (Cronartium sp.) in Shaanxi Province. Journal of Northwest Forestry College 6, 8-12.

Zheng, W.J., ed., 1983: Records of Chinese Trees. Beijing, China: China Forestry Publishing House.

Zhong, J.W.; Sun, L.J.; Wang, S.Z.; PiAO, Z.C.; JiAng, S.L.; Wang, Y.S., 1990: Integrated control of blister rust in Korean pine plantation. Journal of Northeast Forestry University 18, 89-95. 